\title{
The biological activity of soil in Norway spruce forests and in fern Athyrium distentifolium Tausch ex Opiz stands on deforested polluted sites in the Beskydy Mts.
}

\author{
I. Tůma, D. Tůmová, J. Záhora
}

Department of Agrochemistry, Soil Science, Microbiology and Plant Nutrition, Faculty of Agronomy, Mendel University in Brno, Zemédèlská 1, CZ-61300 Brno, Czech Republic, E-mail: DitaPavlikova@seznam.cz

\begin{abstract}
Tůmová D., Záhora J., Tůma I. 2014: The biological activity of soil in Norway spruce forests and in fern Athyrium distentifolium Tausch ex Opiz stands on deforested polluted sites in the Beskydy Mts. - Beskydy, 7 (1): 9-20

The study is focussed on the biological activity of acid forest soil with aim to characterize some of its parameters. Activity of acidic soil phosphatase, basal and potentional respiration were compared and viable plate counts of microorganism colonies were evaluated. The soils of the Kněhyně region in the Moravian-Silesian Beskids Mts. are intensively influenced by acid deposition. They were sampled from area where often occurrence of fern Athyrium distentifolium Tausch ex Opiz was recorded. Above mentioned characteristics (values of parameters) were determined in soil samples collected in fern stands (close to the periphery of fern individuals with rich root system), from site between individual ferns and from the rest of neighbouring spruce community without distinct herbage layer. In majority of studied cases, increased values of all monitored parameters were found in space of A. distentifolium roots accumulated close by fern base. Bare soil between individual fern plants often shows on a lower biological soil activity, however these differences were mostly not statistically significant. On the contrary, values of studied soil parameters recorded in the rest of neighbouring forest community without distinct herbage layer, reached mostly the lowest values and they often differ significantly from values assessed in soil taken near the A. distentifolium roots.
\end{abstract}

Key words: Athyrium distentifolium Tausch ex Opiz, basal and potential respiration, phosphatase activity, forest soil, viable plate counts of cells.

\section{Introduction}

In the course of the last forty years of twenty century, high concentrations of pollutants af́fected forest ecosystems. Large areas of spruce stands of mountains in the Central Europe were damaged due to their decline and calamities. Soil acidification conspicuously affects environments of the herbage layers of forests (Fiala et al. 2007, 2011). The process of acidification was accelerated by the replacement of original mixed forest by spruce monocultures and above all by the input of acidic deposition (Klimo, Vavř́iček 1991). Higher atmospheric depositions of nitrogen resulted in its higher availability for plants in comparison with other elements.
Vegetation there before limited by nitrogen is now limited by phosphorous or other elements (Falkengren-Grerup, Dieckmann 2003). Results of many studies shown, that shifts in availability of nitrogen and phosphorus lead in changes of vegetation composition and species diversity (Güssewell 2004). This situation also occurred in the Moravian-Silesian Beskids Mts., where damaged Norway spruce stands were on large areas substituted by grass stands (Fiala et al. 1998). Expanding fern (Athyrium distentifolium) also occurred on deforested areas of the Mt. Kněhyně (Holub, Tůma 2010) and was described in other mountains of the Central Europe (Vacek et al. 1999). 
Rhizosphere processes belong to the one of the most important processes allowing to study how plants can affect nutrient cycles (Grayston et al. 1996). The nutrient cycling in rhizosphere affects the nutrient uptake by plant roots, amount of rhizogenous exudates and interactions among microorganisms, which are important for maintaining the forest growth and ecosystem stability, especially in conditions poor in nutrients (Gobran et al. 1998).

Observations of soil features, including soil micro-oganisms, belong to the useful tools of biomonitoring, which determine also soil activity and quality (Trávničková 2009). The activity of soil enzymes is a good indicator of changes of soil features (Acosta-Martinez, Tabatabai 2000). Activity of soil phosphatase is very important characteristic contributing to the information about movement of phosphorus in ecosystems, including also important knowledge about metabolic activity of soil (Rejšek 1991). There are also other parameters, which help to characterize soil activity, such as basal and potential soil respiration and assessment of microorganism numbers of individual physiological groups.

The analysis of enzyme activities is useful for long-term monitoring of changes in both health and soil quality (Ekenler, Tabatabai 2004). It was confirmed, that changes in the management of soil are reflected in quantity of microbial biomass and soil enzymes already in a short period of time, and a long time before, than some measurable-visible changes can be found in soil organic matter (Powlson et al. 1987).

The aim of the study was to assessed biological activity and values of some parameters of acid soils beneath different plant communities occurring at the SW slope of the Mt. Kněhyně in the Moravian-Silesian Beskydy Mts., greatly affected by acid depositions. The vegetation of region is characteristic by frequent occurrence of fern Athyrium distentifolium Tausch ex Opiz. The activity of acid soil phosphatase, basal and potential respiration and number of soil microorganisms in various physiological groups were determine in soil samples taken in the following three sites: in the original Norway spruce stand without ferns, in the centre of large gaps - in empty area between fern stands, and in dense fern stands, at the periphery of the fern plants with rich root system.

Present paper comprises of a part of results obtained at widely research activities concerning to temporary herbage communities spreading on immission barrens in disturbed forest communities. Our basic assumption is that stands of Athyrium distentifolium fern can contribute to temporary maintenance of acceptable soil conditions and stabile nutrients cycles on forest barrens created after degradation of current mountain ecosystems. The spruce monocultures are affected by climatic changes linked with additional antropogeneous influences, resulting in temporarily expanding grass communities. The following partial hypotheses were investigated: (i) There are differences in phosphatase activities in nearest surroundings of $A$. distentifolium roots, in soil situated between individual fern stands and in the soil of rest of original forest communities. (ii) Total activity of soil microorganisms, linked with their number in root sphere of ferns, differs against activity microorganisms in soil situated between individual fern plants or activities of soil microorganisms in the rest of original forest communities.

\section{Material and methods}

\section{Study site}

Studies of the soil biological activities were conducted on a southwest-facing slope of the Mt. Kněhyně $\left(49^{\circ} 31^{\prime} \mathrm{N}, 18^{\circ} 32^{\prime} \mathrm{E}, 1140\right.$ m a. s. l.) in the Moravian-Silesian Beskids Mts., i.e., in the western Carpathians near border of the Czech and the Slovak Republics. The studied sites were a partly damaged Norway spruce stand without understory vegetation and a large gap $(15 \times 20 \mathrm{~m})$ caused mostly by wind throw disaster. The area is characterized by an annual mean air temperature of $5.6^{\circ} \mathrm{C}$ and mean sum of annual precipitation of $1102 \mathrm{~mm}$ (Tůma et al. 2012). Sandy loam Spodo-dystric Cambisols occurring on studied sites (Fiala et al. 2011) were formed from Flysh godulian sandstone. Soil samples were taken from $\mathrm{Ol}$ to Ae horizons. During the growing seasons (1997-1999) attained in average wet depositions near the top of the Mt. Kněhyně $25.3 \mathrm{~kg} \mathrm{SO}_{4}{ }^{2-} \mathrm{ha}^{-1}$ and $22.8 \mathrm{~kg} \mathrm{~N}$ ha $^{-1}$ (Fiala et al. 2005). Input of nitrogen in wet depositions measured during studied growing seasons (2007, 2009 and 2008) attained 11.3, 11.9 and $20.6 \mathrm{~kg} \mathrm{~N}^{-1}$, respectively, and the $\mathrm{pH}$ values were 5.01, 5.22 and 5.06 (Tůma et al. 2012).

\section{Soil sample collection}

Soil samples were collected in fern stands close to the periphery of fern individuals with rich root system (roots of fern), in empty areas between fern plants (between fern plants) and in the original spruce forest, without tall ferns (forest stand). 
Soil samples were taken in the spring, summer and autumn 2009 and 2010. Cylindrical metal auger $5 \mathrm{~cm}$ in diameter was used for sampling the soil from 0 to $15 \mathrm{~cm}$ layer, where about $90 \%$ of total root dry mass of tall ferns was accumulated (Fiala et al. 2011).

\section{Soil analysis}

In order to describe features of studied soils, analyses of total N, P K, Ca and Mg were made at the AGROLAB company in Troubsko near Brno. Greater parts of soil samples as skeleton, plants and easily noticeable soil animals were removed. After 24 hours of drying at the laboratory temperature, soil samples were sieved using mesh size of $2 \mathrm{~mm}$, grind and homogenized. From soil characteristics were determined the $\mathrm{pH}$ values (in $\mathrm{H}_{2} \mathrm{O}$ and $\mathrm{KCl}$ ) electrometrically and the loss on ignition at $530^{\circ} \mathrm{C}$. Melich III procedure was used and releasable contents of $\mathrm{Ca}^{2+}, \mathrm{Mg}^{2+}$ and $\mathrm{K}^{+}$were determined with help of atomic-absorption spectroscopy. Content of $\mathrm{P}$ was determined photometrically as a molybdate-phosphatecomplex and total $\mathrm{N}$ by distillation after mineralization of fine earth (Kjeldahl technique).. The values of water holding capacity (WHC) and soil dry matter were determined and soil samples in polythene bags were stored at the temperature of $4-8{ }^{\circ} \mathrm{C}$ for four weeks. Prior to the start of experiment, soil was adjusted at $70 \%$ of WHC.

\section{Phosphatase activity}

Determination of phosphatase activity was provided according to modification of method described by Tabatabai, Bremner (1969). The determination of phosphatase activity consists of the measurement of the formation of ester hydrolysis products. The course of the reaction is measured spectrophotometrically. Method uses $p$-nitrophenylphosphate (pNPP) as the substrate. It is a chromogenic substrate, which is during reaction changed in yellow coloured 4-nitrophenolate anion, emerged as $p$ nitrophenol (pNP) (Horáková et al. 2007). pNP is subsequently determined spectrometrically. Activity of phosphatases is expressed in nmol ${ }_{\mathrm{pNP}} \cdot \mathrm{mg}_{\mathrm{dm}}^{-1} \cdot \mathrm{min}^{-1}$.

\section{Soil respiration}

In order to estimate both basal and potential intensity of soil respiration, the method based on $\mathrm{CO}_{2}$ production absorbed by natrocalcide was used. Soil was adjusted at $70 \%$ of WHC. Measurements of dry mass of natrocalcide took place daily in the course of 22 days. Due to an increase in natrocalcide mass, which is directly proportional of soil microbial activity, amount of $\mathrm{CO}_{2}$ respiration was assessed. Results are expressed as cumulative content of $\mathrm{CO}_{2}-\mathrm{C} . \mathrm{kg}^{-1}$ (ISO/DIS 16072, 2002).

\section{Estimation of number of micro-organisms by cultivation}

In order to estimate the abundance of micro-organisms belonging to important group, cultivation plate method was used, based on determination of number of arised colony on hardened soils (ČSN EN ISO 6887-1). The following physiological groups of microorganisms were quantitatively determine with the help of the cultivation plate method: total number of micro-organisms, total number of sporulating micro-organisms, counts of actinomycetes and number of micromycetes. Number of microorganisms is expressed in CFU (Colony-forming units). $g^{-1}$.

\section{Statistical analysis}

Obtained results were evaluated statistically by the one factorial analysis of variance and significant differences were detect by the Tuckey test $(P<0,05)$ with help of Statistica 8.01. Values of phosphatase activities were compared with other obtained values of chosen parameters with help of correlation analyse $(\mathrm{P}<0.05)$.

\section{Results and discussion}

Fern stand enhanced C, N, K, P and Mg pool sizes in soils (Tab. 1). Averaged C, $\mathrm{N}$ and $\mathrm{P}$ stocks in soils increased by 39,44 and $115 \%$, respectively, in root space of ferns in comparison with forest stand (Tab. 1).

The values of acidic phosphatase found in soil samples collected in 2009 and 2010 increased from spring to autumn (Fig. 1, 2). However, Rejšek (1991) found that activity of acidic phosphates had in similar conditions of forest soils two peaks. The spring maximum was much the same of autumn maximum and the lowest values were recorded in July, probably, due to decline of the soil moisture in this period.

We can generally say, that assessed phosphatase activities were during year inversely related to the distance from fern individuals (Fig. 1, 2). Thus the highest values of phosphatase activity were recorded in most cases immediately in root space of ferns. Values of activities of acidic phosphatase assessed in soils of empty areas between fern stands were insignificantly lower, in comparison with results recorded in fern root space. However, in most of the collected samples (period of year, year of collection), statistically 
Tab. 1: Soil reaction and mean contents of nutrient in 0-15 cm soil layer.

\begin{tabular}{c|c|cccccccc}
\hline $\begin{array}{c}\text { Season } \\
\text { of year }\end{array}$ & Variants & ${ }_{\mathrm{p}} \mathrm{H}_{\mathrm{KCl}}$ & ${ }_{\mathrm{p}} \mathbf{H}_{\mathrm{H}_{2} \mathbf{O}}$ & $\begin{array}{c}\mathbf{C a} \\
\left(\mathbf{m g . k g}^{-1}\right)\end{array}$ & $\begin{array}{c}\mathbf{M g} \\
\left(\mathbf{m g . k g}^{-1}\right)\end{array}$ & $\begin{array}{c}\mathbf{P} \\
\left(\mathbf{m g . k g}^{-1}\right)\end{array}$ & $\begin{array}{c}\mathbf{K} \\
\left(\mathbf{m g . k g}^{-1}\right)\end{array}$ & $\begin{array}{c}\mathbf{N} \\
(\%)\end{array}$ & $\begin{array}{c}\text { Loss of ign. } \\
(\%)\end{array}$ \\
\hline \multirow{2}{*}{$\begin{array}{c}\text { Spring } \\
\mathbf{2 0 0 9}\end{array}$} & $\begin{array}{c}\text { Forest stand } \\
\text { Between } \\
\text { fern plants } \\
\text { Roots of fern }\end{array}$ & 3.15 & 3.90 & 49.75 & 8.05 & 5.80 & 5.35 & 0.54 & 11.31 \\
& 2.90 & 3.70 & 36.25 & 7.10 & 8.25 & 5.30 & 0.63 & 12.20 \\
Spring & $\begin{array}{c}\text { Forest stand } \\
\mathbf{2 0 1 0}\end{array}$ & 3.10 & 3.60 & 43.80 & 9.00 & 17.00 & 7.80 & 0.80 & 16.32 \\
& $\begin{array}{c}\text { Between } \\
\text { fern plants } \\
\text { Roots of fern }\end{array}$ & 2.90 & 3.45 & 37.90 & 6.65 & 7.20 & 6.25 & 0.63 & 11.52 \\
\hline
\end{tabular}

significant differences were found between values of acidic phosphatase found in root space of fern and control soil of spruce forest without undergrowth. In spring 2009 represented the activity of acidic phosphatase in soil of spruce forest only $34 \%$ of activity found in root space of ferns, but in summer as many as $79.2 \%$ and in autumn $77.0 \%$. Similar results were recorded in 2010. The values of activity of acidic phosphatase of forest soil reached only $32.6 \%$ in spring, $77.2 \%$ in summer and in autumn $79.5 \%$ of values recorded in root space of ferns. The activity of acid phosphatase was in each year inversely related to distance from root space of fern (Figs. 1,2 ). Thus our hypothese was confirmed, since there were differences in phosphatase activities in sphere of fern roots and soils of other habitats.

There were determined strong positive correlations between activity of acid phosphatase and content of phosphorus $(r=0.8326, n=12)$ and carbon $(\mathrm{r}=0.7218, \mathrm{n}=12)$ in soil. Activity of acid phosphatese correlated negatively with soil $\mathrm{pH}$ $(\mathrm{r}=0.8559, \mathrm{n}=12)$.
Our results correspond with findings of several other authors that there is a specific dependence between activity of phosphatase and nutrient contents in soil. For example, there was a positive correlation between activity of acidic phosphatase and the content of organic carbon in soil samples collected in the Czech Republic (Šarapatka 2003). These findings corresponded also with results of other authors, e.g., Gehlen and Schroder (1990), Nahas et al. (1994) and others. Activity of enzymes decreased with decreasing amount of total organic $\mathrm{C}$ in soil (Beyer et al. 1999), how it was observed in different intensively cultivated agriculture soils. A positive correlation was also found between content of $\mathrm{N}$ in soil and phosphatase activity (Bonmati et al. 1991). Aon, Colaneri (2001) described strong relations between the both organic $\mathrm{C}$ and total $\mathrm{N}$ and activities of enzymes including acidic phosphatases.

Other authors recorded a positive correlation between the activity of acidic phosphatase and the content of total inorganic phosphorus (Chhonkar,Tarafdar 1984; Amador et al. 1997,

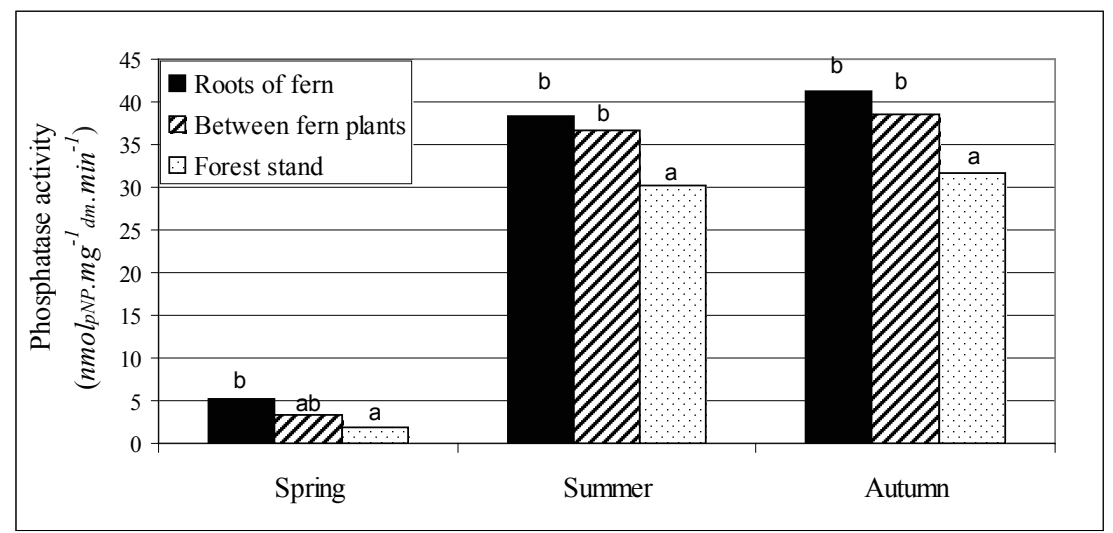

Fig. 1: Activity of acidic phosphatase in soils of various sites during different seasons of 2009. Values with different letters are statistically significant (ANOVA, Tukey test, $P<0.05$ ). 


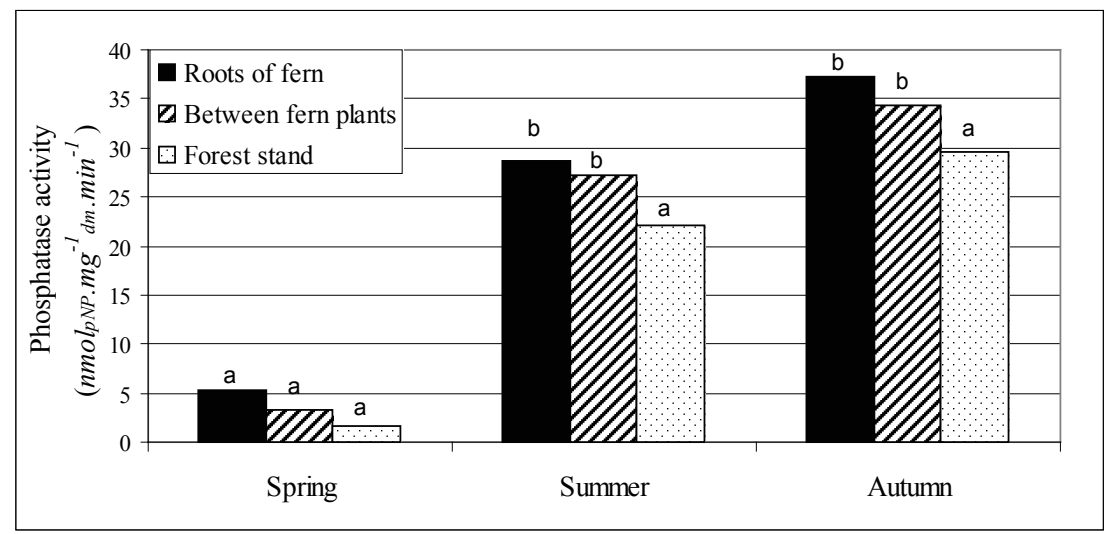

Fig. 2: Activity of acidic phosphatase in soils of various sites during different seasons of 2010. Values with different letters are statistically significant (ANOVA, Tukey test, $P<0.05$ ).

Šarapatka 2003). On the contrary, Speir and Ross (1978), as well as Haynes, Swift (1988) observed a negative correlation between content of available $\mathrm{P}$ and the acid phosphatases.

Abundance of chosen physiological groups of microroganisms was determined in the same periods of years and at the same locality as activity of phosphatases. In most cases, total number of microorganisms (Fig. 3) and number of sporulating microroganisms (Fig 4) were the greatest in samples collected from root space of A. distentifolium species. A bit lover values were recorded in the empty areas between fern plants. But their numbers in rhizosphere were significantly different only in spring months. In soil of forest stand, significantly lower total number of microorganisms was determined than in space of fern rhizosphere. Their amount was even 3.5 times lower and number of sporulating microorganisms was more than five times lower. Our results correspond with previously published data by Szostková and Záhora (2007) who have found that amount of bacterium and bacterial spores were even three times higher in soil taken closely at the periphery of A. distentifolium plant than in empty areas without ferns. We found similar relationships when compared number of actinomycetes (Fig. 5). The highest values were in soil near ferns. The lowest numbers of actinomycetes (statistically significantly different in spring and autumn period) were found in soil samples collected in control habitat of adjacent forest. Number of micromycetes was the highest (in comparison with forest soil significantly) in soil take in rthizosphere of ferns but only in samples of spring collection (Fig. 6).

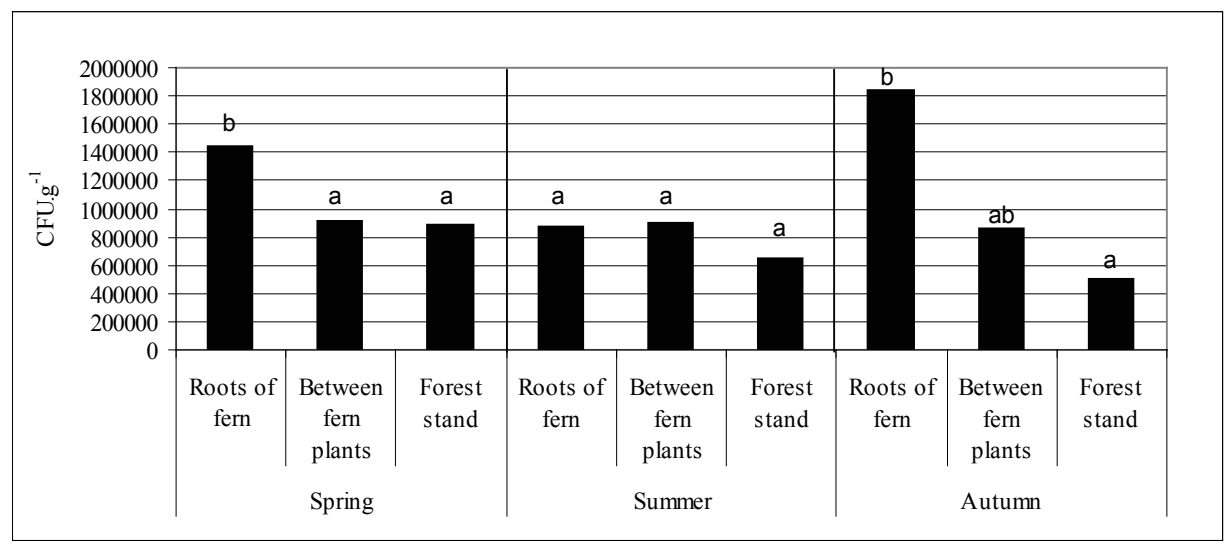

Fig. 3: Total number of micro-organisms in soils of various sites during seasons of 2010. Values with different letters are statistically significant (ANOVA, Tukey test, $P<0.05)$. 


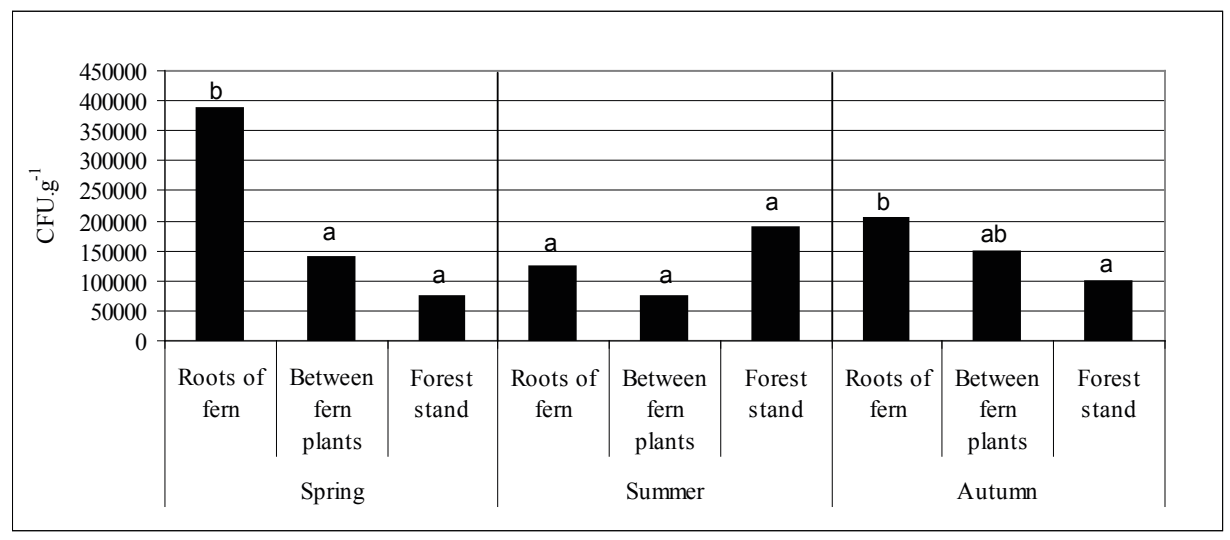

Fig. 4: Number of sporulating micro-organisms in soils of various sites during seasons of 2010. Values with different letters are statistically significant (ANOVA, Tukey test, $P<0.05$ ).

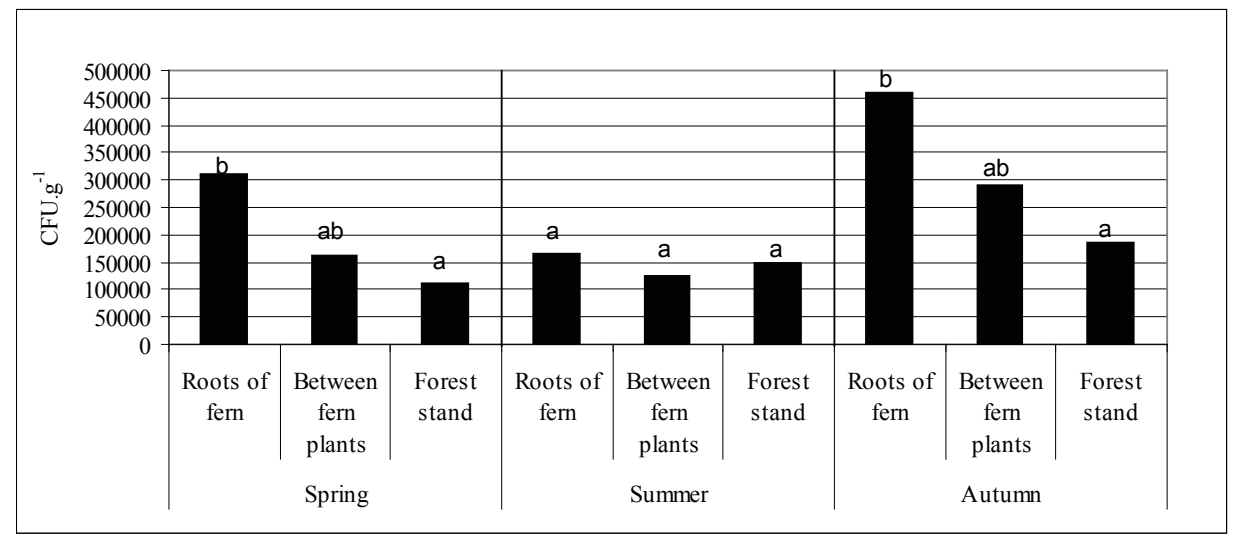

Fig. 5: Number of actinomycetes in soils of various sites during seasons of 2010. Values with different letters are statistically significant (ANOVA, Tukey test, $\mathrm{P}<0.05)$.

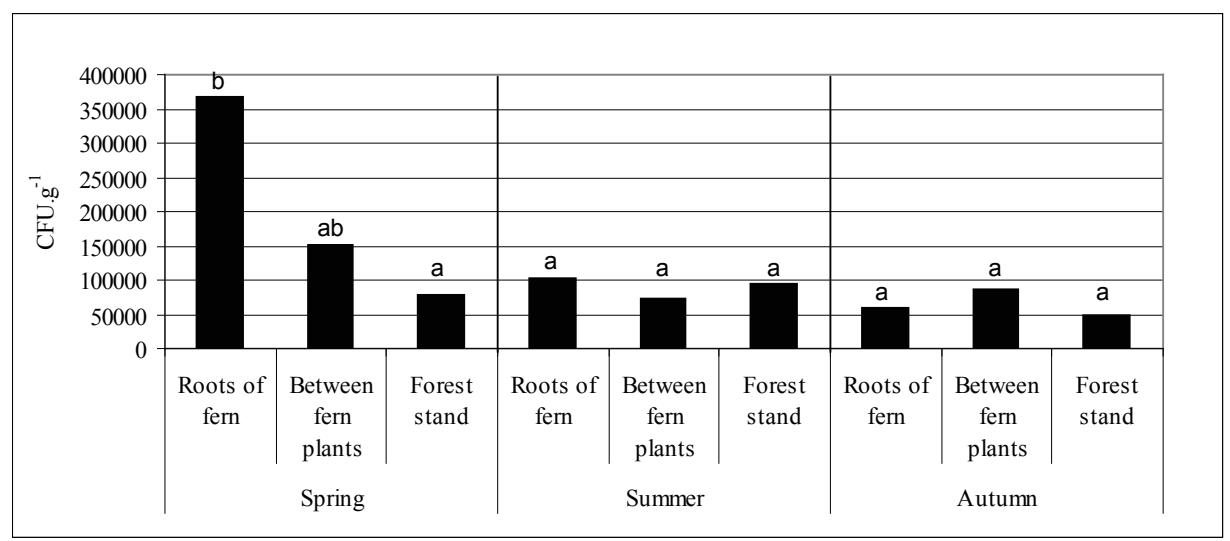

Fig. 6: Number of micromycetes in soils of various sites during seasons of 2010. Values with different letters are statistically significant (ANOVA, Tukey test, $P<0.05$ ). 
It follows from above mentioned facts that the surrounding of roots (rhizosphere) of the fern A. distentifolium affects conspicuously occurrence and activity of microorgansms. In consequence of this fact, the increase of phosphatase activity correlated positively with number of actinomycetes $(r=0.8145)$ and number of total microroganisms $(\mathrm{r}=0.865)$.

Our assumption was confirmed since we can conclude, that rhizosphere of tall fern Athyrium distentifolium can conspicuously and positively affect abundance and activity of soil microorganisms. As a result of this fact, phosphatse activity increased. Positive correlations between abundance of microorganisms and activity of phosphatase was found also by several other authors (e.g., Tate and Terry 1980, Raiesi and Ghollarata 2006). Nevertheless, Šarapatka (2003) did not find such correlations in forest soils.

Activity of soil microorganisms in soil samples was assessed also based on determination of basal and potential respiration. Cumulative development of basal and potential respiration was observed in the course of 22 days (Fig. 7, 8). The results shown that potential respiration was in most cases higher than basal respiration. The greatest cumulative increment found in the initial phases of the experiment was in potential respiration particularly, and after supply of easy decomposed substrate in the form of glucose. It can be connected with fast development of groups of microorganisms specialized on utilization of these easy decomposed substances ( $\mathrm{r}$ strategist). In the further days, when microrganisms utilized added substrate and started to use badly decomposable substances, the increment had been already slow.

The trend of cumulative increments of basal respiration was relatively stable during whole time of experiment, due to the community of microorganisms presented in collected soil samples. It was given by soil composition, availability of important nutrients and soil organic matter. Stable laboratory conditions (constant moisture and temperature) also supported this process. There are ideal temperature conditions for mesophile soil microrganisms. Both favourable temperature and the sufficiency of easy decomposable substances can lead to an increase of respiration at the beginning of exposition.

In the spring period of 2009 , values of basal respiration of micro-organisms in the rhizosphere distinguished from described trends, because they nearly reached values of potential respiration. This fact can be caused by higher content of easy decomposable organic substances in the form of root exudates associated with root activities in spring period of this year. On the contrary, soil temperature was higher in 2010. This fact can resulted in greater activity of below-ground organs of ferns. It can be reason why soil sample may be sufficiently enriched by easily decomposable organic substances and show so high respiration activity of microorganisms, which did not substantially increase even by the secondary application of glucose.

Values of the total amount of carbon, released in the course of the whole laboratory experiment, are given in Figure 9. Results of basal respiration are given in the left part of the figure and reflect real activity of soil microoganisms. Average values of both years show on a higher basal respiration of soil samples taken in spring period in contrast to results recorded in summer and autumn. This fact can be explained by the occurrence of sufficient amount of precipitation, increasing temperature and sufficient amount of organic matter from fresh autumn litter. But due to the increase of spring root activities, especially, connected with production of exudates, supporting conspicuously activity of microorganisms. If we compare values of basal soil respiration of individual variants recorded during whole time of the experiment, we found the highest respiration activity (statistically significant) in soil taken in A. distentifolium root space in contrast to soil samples collected in forest.

As a potential respiration is considered an increase of respiration rate, which occurs after supply of easily usable substrate (Šantrůčková 1993). In our case, it is solution of glucose, enabling the maximal activity of soil microbial community in conditions of an optimal availability of organic substances. Our obtained data are given in the right part of the Figure 9. These are higher values than were found for basal respiration. Similarly as basal respiration, potential respiration was even higher (in two seasons from three) in fern root space in contrast to forest soil without herbage layer. Generally it is known, that there is the highest amount of soil microorganisms in plant rhizosphere than in free soil (Kennedy 1998), since they are substantially supported by means of amount of released root exudates. Thus microroganisms, even in our case, can be supported by easily decomposable organic substances serving as a source of biogenic nutrients and energy. Just this fact can be associated with increased microbe activity resulted in higher values of respiration.

Similarly as in the soil samples collected in root space of fern, a higher activity of phosphatase was also assessed in similar cases. The 


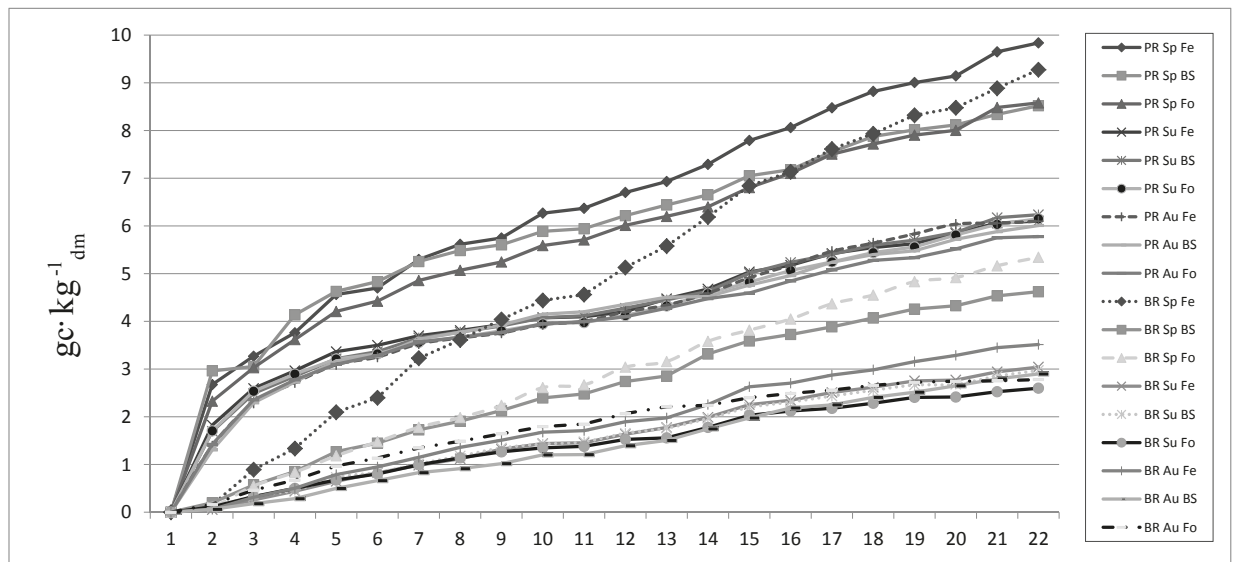

Fig. 7: Cumulative amounts of released carbon for basal and potential respiration in soils of various sites during seasons of 2009. PR - potential respiration, BR - basal respiration, Sp - spring, Su - summer, A u - autumn, Fe - roots of fern, BS - between fern plants, Fo - forest stand.

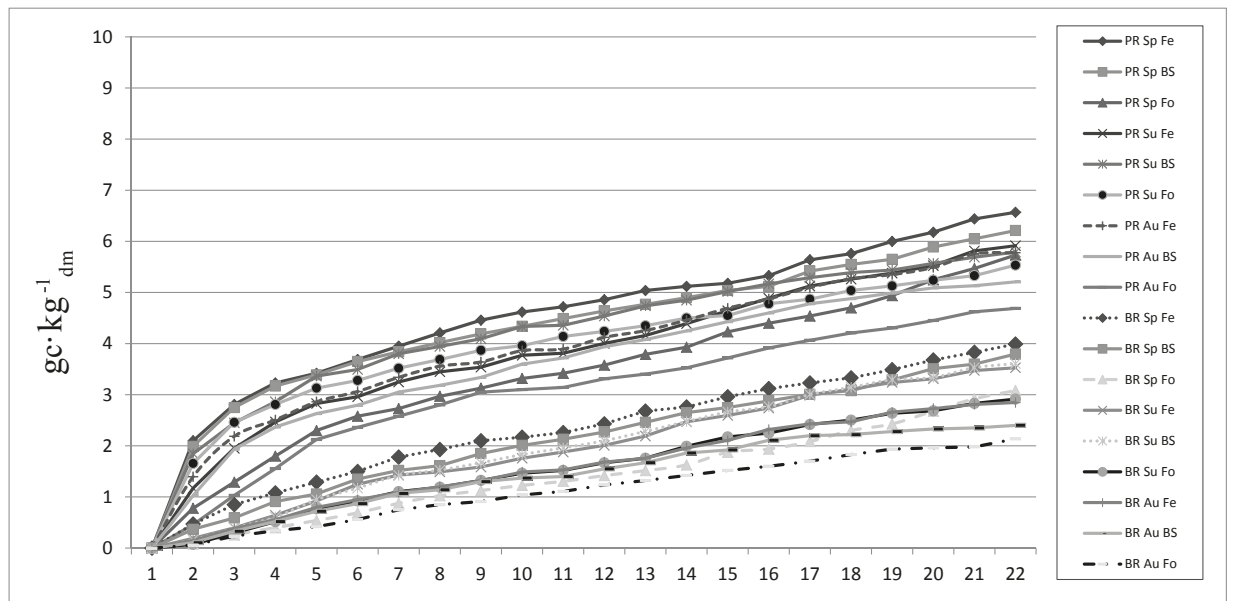

Fig. 8: Cumulative amounts of released carbon for basal and potential respiration in soils of various sites during seasons of 2010. PR - potential respiration, BR - basal respiration, Sp - spring, Su-summer, Au - autumn, Fe - roots of fern, BS - between fern plants, Fo - forest stand.

highest numbers of physiological groups of microorganisms were also found in the vicinity of roots. Soil taken in root space of fern contained higher amounts of total $\mathrm{N}$ and $\mathrm{C}$. Content of available phosphorus is higher too. This fact can be associated with higher activity of phosphatase, which can be reflected in increased total activity and recorded amount of soil microorganisms, whereby the cycle of dependence and conditions can be closed.

In the contrary to basal respiration, potential respiration was two times higher in soil taken in the forest and in the empty area between fern plants. This fact shown, that there was some gradual shortage of easily usable organic substrate in soil.
The above mentioned facts can confirm the second hypothesis. It means that total activity of soil microorganisms (soil respiration) and their number in nearest surrounding of A. distentifolium roots, differ against both the activity of soil microrganisms between individual ferns and in soil of remnants of original forest communities.

These results confirm also our partial hypotheses and can contribute to a more complex answer to our basic hypothesis. Whether stands of Athyrium distentifolium can contribute in certain range to temporary maintenance of acceptable soil relations and stable nutrient cycles on forest barens developed due to dying of trees of current mountain forest ecosystems under impact of climatic changes linked with other 


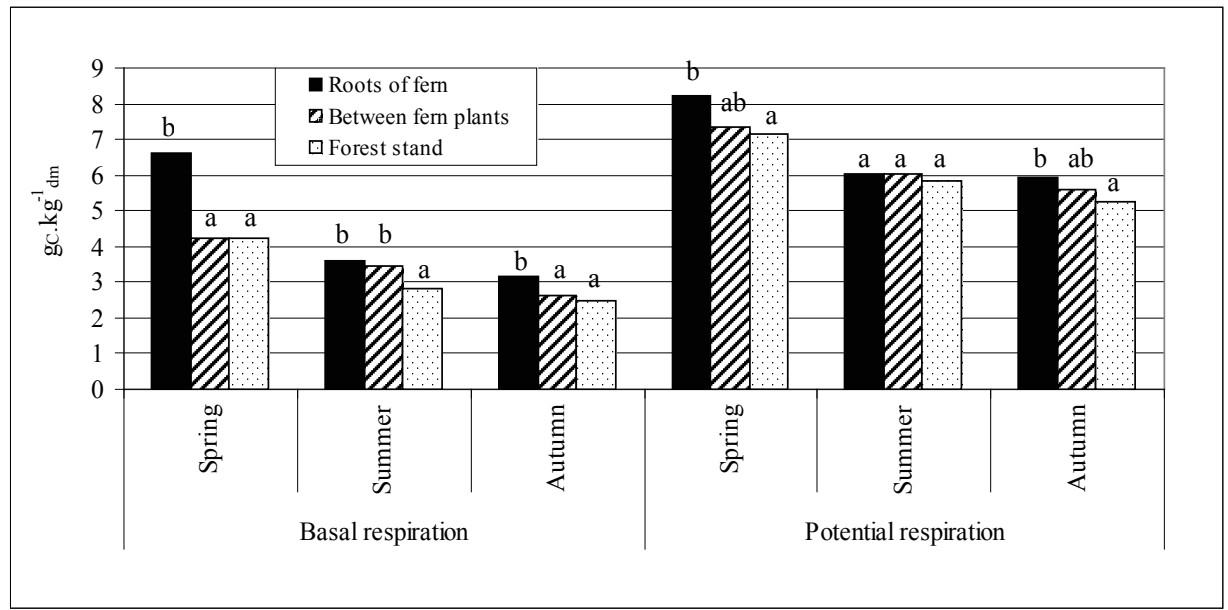

Fig. 9: Total amount of respired carbon for basal and potential respiration in soils of various sites during seasons of 2009 - 2010. Values with different letters are statistically significant (ANOVA, Tukey test, $P<0.05$ ).

antropogeneous influences, similarly how it is in substitute grass communities.

However, there are opinions that a negative role of fern stands on growth or survive of young seedlings of woody plants exist (Vacek et al. 2012). George and Bazzaz (1999) studied the influence of $A$. distentifolium fern stands on regeneration of disturbed forests. According to these authors, fern stand determine species composition, size structure and spatial distribution of seedlings, since it affects differentially their growth and development. How it is apparent from literature other authors (Horsley and Marquis 1983; Pacala et al. 1994) the effect of fern on growth and survival of seedlings can not be explicitly negative, therefore this important problem needs further studies.

Results, described in the present paper, show on increasing activity of phosphatase and soil microorganisms in fern stands, which can, in later years, conspicuously contribute to making nutrients available. Nutrients were temporarily bounded in fern biomass and in its slowly decomposing litter or standing dead leaves, which were available later after disintegration of compact stands for seedlings arising in the course of subsequent succession. Although some authors found a lower survival of tree seedlings in A. distentifolium stands due to the effect of greater shadows, seedlings of tree can emerge in older fern stands, where disintegration of compact cover occurs. They can take advantage of above mentioned nutrients (for example due to a higher phosphatase activity) releasing from decomposing of A. distentifolium biomass. Similarly it is in seedlings growing on decayed trunks of fallen trees or stumps or growing in base of still standing dead trunks on the contrary of young seedlings germinating on raw coniferous humus covering forest soil of open areas.

\section{References}

Acosta-Martínez, V., Tabatabai, M.A. 2000: Enzyme activities in a limed agricultural soil. Biology and Fertility of Soils, 31: 85-91.

Amador, J.A., Glucksman, A.M., Lyons, J.B., GORRES, J.H. 1997: Spatial distribution of soil phosphatase activity within a riparian forest. Soil Science, 162: 808-825.

Aon, M.A., Colaneri, A.C. 2001: Temporal and spatial evolution of enzymatic activities and physico-chemical properties in an agricultural soil. Applied Soil Ecology, 18: 255-270.

Beyer, L., Sieling, K., Pingrank, K. 1999: The impact of a low humus level in arable soils on microbial properties, soil organic matter quality and crop yield. Biology and Fertility of Soils, 28: 156-161.

Bonmati, M., Ceccanti, B., Nannipieri, P. 1991: Spatial variability of phosphatase, urease, protease, organic carbon and total nitrogen in soil. Soil Biology and Biochemistry, 23: 391-396.

Chhonkar, P.K., Tarafdar, J.C. 1985: Degradation of clay enzyme comlexes by soil microorganisms. Zentralblatt Mikrobiol, 104: 471-474.

Ekenler, M., Tabatabai, M.A. 2004: Arylamidase and amidohydrolases in soils as affected by liming and tillage systems. Soil and Tillage Research, 77: 157-168. 
Falkengren-Grerup, U., Diekmann, M. 2003: Use of a gradient of $\mathrm{N}$-deposition to calculate effect-related soil and vegetation measures in deciduous forests. Forest Ecology and Management, Elsevier, 180: 113-124.

Fiala, K., Tưma I., Jakrlovấ J., Ježírovấ M., SedLÁKovÁ I.,t Holub P. 1998: The role of grass ecosystems of deforested areas in the region affected by air pollution (the Beskydy Mts., the Czech Republic). Ekológia, (Bratislava), 17: 24l-255.

Fiala K., Túma I., Holub P., JandÁK J. 2005: The role of Calamagrostis communities in preventing soil acidification and base cations losses in a deforested mountain area affected by acid deposition. Plant Soil, 268: 35-49.

Fiala K., Túma I., Holub P. 2007: Porosty trav na odlesněných plochách - nežádoucí buřeň? [Stands of grasses on deforested areas - unwanted weeds?] Živa, 5: 203-205.

Fiala, K., TÚma, I., Holub, P., ZÁhora, J. 2011: Ecological analysis of herbage layer of disturbed spruce stands in the National Nature Reserve Kněhyně-Čertův mlýn in the Beskydy Mts. Ekológia, 3: 381-395.

Gehlen, P., Schroder, D. 1990: Bedeutung von pH Wert, Corg. Gehalt, Kultur, Substrat und Jahreseinfluss für bodenmikrobiologische Eigenschaften in einheitlich genutzten Akkerboden. Verband Deutscher Landwirtschaftlicher Untersuchungs und Forschungsanstalten, 30: 467-472.

George L.O., Bazzaz F.A. 1999: The fern understory as an ecological filter: growth and survival of canopy-tree seedlings. Ecology, 80(3): 846-856.

Gobran, G. R., ClegG, S., Courchesne, F. 1998: Rhizospheric processes influencing the biogeochemistry of forest ecosystems. Biogeochemistry, 42: 107-120.

Grayston, S.J., Vaughan, D., Jones, D. 1996: Rhizosphere carbon flow in trees, in comparison with annual plants: the importance of root exudation and its impact on microbial activity and nutrient availability. Applied Soil Ecology, 5: 29-56.

GüSEWELL, S. 2004: N:P ratios in terrestrial plants: variation and functional significance. New Phytologist, 164: 243-266.

HAYNES, R.J., SWIFT, R.S. 1988: Effect of lime and phosphate additions on changes in enzyme activities, microbial biomass and levels of extractable nitrogen, sulphur and phosphorus in acid soil. Biology and Fertility of Soils, 6: 153-158.

Holub, P.,TŮma, I. 2010: The effect of enhanced nitrogen on aboveground biomass alloca- tion and nutrient resorption in the fern Athyrium distentifolium. Plant Ecology, 207: 373-380.

Horáková, D., Němec, M., Szostková, M. 2007: Laboratorní cvičení z fyziologie bakterií [Laboratory exercises of physiology of bacteria]. Brno. Masarykova univerzita $\mathrm{v}$ Brně. Př́írodovědecká fakulta. Skripta: 39-43.

Horsley, S.B., Marquis, D.A. 1983: Interference by weeds and deer with Allegheny hardwood reproduction. Canadian Journal of Forest Research, 13: 61-69.

ISO/DIS 16072: 2002. Soil quality. Laboratory methods for determination of microbial soil respiration.

KENNEDY, A.C. 1998: The rhizosphere and spermatosphere. In: Funrmann J. J. et al., eds. Principles and applications of soil microbiology. DM Sylvia, Prentice Hall Inc, Upper Saddle River: 389-409.

Klimo, E., VAVŘíčeK. D. 1991: Acidifikace a vápnění lesních půd $\mathrm{v}$ Beskydech [Acidification and and liming of forest soils in the Beskydy Mts.]. Lesnictví, 37: 61-68.

Nahas, E. Centurion, J.F., Assis, L.C. 1994: Efeito das caractericas quimicas dos solos sobre os microorganismos solubilizatores de fosfato e produtores de fosfatases. Revista Brasileira de Ciencia de Solo, 18:49-53.

Pacala, S.W., Canham, C.D., Silander, J.A., Jr., Kobe, R.K. 1994: Sapling growth as a function of resources in a north temperate forest. Canadian Journal of Forest Research, 24: 2172-2183.

Powlson, D.S., Brookes, P.,Christensen, B.T. 1987: Measurement of soil microbial biomass provides an early indication of changes in total soil organic matter due to straw incorporation. Soil Biology and Biochemistry, 19: 59-164.

Raiesi, F., Ghollarata, M. 2006: Interactions between phosphorus availability and an AM fungus (Glomus intraradices) and their effects on soil microbial respiration. Pedobiologia, 50: 413-425.

REJŠEK, K. 1991: Vliv antropogennízátěže lesnípiody na zmèny aktivity kyselé fosfomonoesterázy [The influence of anthropogenic impact of forest land to changes in activity of acid fosfomonoesterase]. Brno. VŠZ v Brně. Doctoral thesis, 160 pp.

SPEIR, T.W., Ross, D.J. 1978: Soil phosphatases and sulphatases. In: Burns, R. G., ed. Soil Enzymes. New York: Academic Press: 197-249.

SzostKová, M., ZĀHORA, J. 2007: Microbial nitrogen transformation in soil covered with Athyrium distentifolium in deforested mountain area. In: Kosalec, I. Power of microbes in 
industry and environment. Book of abstracts. Zagreb, Chorvatsko: Pressum d.o.o.: 139 pp.

ŠANTRŮČKOVÁ, H. 1993: Respirace půdy jako její biologické aktivity. Respiration soil as its biological activity. Rostlinná výroba, 39: 769-778.

ŠARAPATKA, B. 2003: Phosphatase activities (ACP, ALP) in agroecosystem soils. Uppsala. Swedish University of Agricultural Sciences, Uppsala. Department of Ecology and Crop Production Science. Acta Universitatis Agriculturae Sueciae. Agraria. Doctoral thesis: 396.pp.

TAbatabai, M.A., Bremner, J.M. 1969: Use of p-nitrophenol phosphate for assay of soil phosphatase activity. Soil Biology and Biochemistry, 1: 301-307.

TATE, R. L. et TERRY, R. E. 1980: Variation in microobial activity in histosols and its relationship to soil moissture. Applied and Environmental Microbiology, 40: 313-317.

TRÁVníčKovÁ, E. 2009: Využití půdních mikroorganizmů v biomonitoringu - nové poznatky a přístupy. [Utilisation of soil microorganisms in biomonitoring - new knowledge and approaches]. Masarykova univerzita v Brně. Př́rodovědecká fakulta. Recetox. Výzkumné centrum pro chemii životního prostředí a ekotoxikologii,

Tưma I., Fiala K., Záhora J., Holub P. 2012: The role of Athyrium distentifolium in reduction of soil acidification and base cation losses due to acid deposition in a deforested mountain area. Plant Soil, 354: 107-120. ISSN 0032-079X.

Vacek S., Hejcmanová P., Hejcman M. 2012: Vegetative reproduction of Picea abies by artificial layering at the ecotone of the alpine timberline in the Giant (Krkonoše) Mountains, Czech Republic. Forest Ecology and Management, 263: 199-207. 
